\title{
The SSM and the prudential regime of non-performing loans
}

Book or Report Section

Accepted Version

Miglionico, A. (2019) The SSM and the prudential regime of non-performing loans. In: Lo Schiavo, G. (ed.) The European Banking Union and the Role of Law. Elgar Financial Law Series. Edward Elgar Publishing, Cheltenham, pp. 197-214. ISBN 9781788972017 doi:

https://doi.org/10.4337/9781788972024.00017 Available at http://centaur.reading.ac.uk/83491/

It is advisable to refer to the publisher's version if you intend to cite from the work. See Guidance on citing.

To link to this article DOI: http://dx.doi.org/10.4337/9781788972024.00017

Publisher: Edward Elgar Publishing

Publisher statement: This is a draft chapter. The final version is available in The European Banking Union and the Role of Law edited by Gianni Lo Schiavo, published in 2019, Edward Elgar Publishing Ltd http://dx.doi.org/10.4337/9781788972024 The material cannot be used for any other purpose without further permission of the publisher, and is for private use only. 
All outputs in CentAUR are protected by Intellectual Property Rights law, including copyright law. Copyright and IPR is retained by the creators or other copyright holders. Terms and conditions for use of this material are defined in the End User Agreement.

\section{www.reading.ac.uk/centaur}

\section{CentAUR}

Central Archive at the University of Reading

Reading's research outputs online 


\title{
The SSM and the prudential regime of non-performing loans
}

\author{
Andrea Miglionico* \\ * Lecturer, University of Reading, School of Law. E-mail: a.miglionico@reading.ac.uk
}

\begin{abstract}
In the aftermath of the global financial crisis, the rapid rise of non-performing loans (NPLs) showed the fragility of the banking system and the lack of harmonized regulatory regime to address the systemic risk of failing banks. The deterioration of NPLs in the balance sheet of credit institutions represents a real concern for the supervisory authorities and constitutes a challenge for regulators and market actors. This chapter examines the supervision of NPLs taking into consideration the architecture of Single Supervisory Mechanism (SSM) and the role of European Central Bank (ECB) to monitor non-performing exposures. The new supervisory toolkit implemented in the European Banking Union aims to improve the classification of asset quality and to establish common practices to resolve NPLs. This chapter argues that the intricate structure of the preventive measures to reduce the risk of lending defines a new landscape in the prudential treatment of NPLs.
\end{abstract}

Keywords: Non-performing loans, asset quality, prudential regime, non-performing exposures, write-off, bank capital, resolution and restructuring mechanism, credit risk.

\section{Introduction}

The creation of the European Banking Union (hereinafter the 'EBU') with the granting of supervisory powers to the European Central Bank (ECB) ${ }^{1}$ and the increased attention given by regulators to non-performing loans (NPLs) are some of the developments that in the aftermath of the global financial crisis have brought the issue of financial stability back to the fore of legal and economic policy debate. The Single Supervisory Mechanism (SSM) put the ECB directly in charge as the supervisor for the

\footnotetext{
${ }^{1}$ The Single Supervisory Mechanism (SSM) has been established by Council Regulation (EU) No 1024/2013 of 15 October 2013 conferring specific tasks on the European Central Bank concerning policies relating to the prudential supervision of credit institutions [2013] OJ L 287.
} 
largest Eurozone banking groups. ${ }^{2}$ This means that the dominant part of the Eurozone's banking system is monitored by a common EU institution. As noted, 'the underlying economic rationale is that full coordination via centralization of banks' prudential supervision in the [SSM] and resolution in the SRM would result in the highest level of safety and soundness because only this approach allows for full internalization of potential negatives externalities of cross border banking' ${ }^{3}$ The ECB also has the right to inspect smaller Eurozone banks that it does not supervise directly. In substance, the ECB is the direct supervisor of the significant banks for the entire Eurozone banking system. ${ }^{4}$

During the global financial crisis, the banking sector experienced a rapid rise in loan delinquencies and defaults driven by the limitations of the Basel rules and the adequacy of capital. ${ }^{5}$ The crisis revealed that NPLs played a central role in the linkages between credit markets frictions and macroeconomic vulnerabilities. ${ }^{6}$ Espinoza and Prasad have observed that 'in 2009 NPLs increased sharply and credit stagnated, raising worries that the recovery could be slowed down by credit constraints'. ${ }^{7}$ The regulatory treatment to assess the asset quality highlights the lack of common practices to monitor NPLs and the fragility of the banking institutions. Specifically there is no consensus on the definition and classification of NPLs across countries, firms or even within firms different data definitions are dependent on subsidiary and business line. ${ }^{8}$

\footnotetext{
2 The SSM is composed of the ECB and the national competent authorities, with the ECB in charge of its effective and consistent functioning (Article 6(1)). The scope of application of the SSM Regulation comprises all euro area Member States on a compulsory basis and also non-euro area Member States that voluntarily enter into a 'close cooperation' with the ECB (Article 7). The SSM Regulation confers 'specific tasks' related to the prudential supervision of credit institutions to the ECB.

${ }^{3}$ See Maria Nieto and Larry D. Wall, 'Cross-Border Banking on the Two Sides of the Atlantic: Does it Have an Impact on Bank Crisis Management?’, (2015), FRB Atlanta Working Paper, 17.

${ }^{4}$ See Eilís Ferran \& Valia Babis, 'The European Single Supervisory Mechanism', (2013), 13 Journal of Corporate Law Studies, 255. It is noted that 'designing the SSM has been an exercise in sophisticated legal gymnastics to fit within the existing Treaty framework, as well as high stakes political manoeuvring and pragmatic decision-making'.

${ }^{5}$ See Tara Sullivan and James Vickery, 'A Look at Bank Loan Performance', (2013), Federal Reserve Bank of New York. It is pointed out that at the start of 2007, only about 1 percent of bank loan balances were "nonperforming", meaning that the loan was at least ninety days past due or in nonaccrual status. By late 2015, however, the average level of NPLs across the EU banks is 5.9 percent while NPL ratios for the United States and Japan is less than 2 percent. See also World Bank, 'Bank nonperforming loans to total gross loans' available at

http://data.worldbank.org/indicator/FB.AST.NPER.ZS.

${ }^{6}$ See Mwanza Nkusu, 'Nonperforming Loans and Macrofinancial Vulnerabilities in Advanced Economies', (2011), IMF Working Paper, 4. The author observed a negative correlation between NPLs and various macroeconomic variables.

${ }^{7}$ See Raphael Espinoza \& Ananthakrishnan Prasad, 'Nonperforming Loans in the GCC Banking System and their Macroeconomic Effects', (2010), IMF Working Paper, 4.

${ }^{8}$ See David Bholat et al, 'Non-performing loans: regulatory and accounting treatment of assets', (2016), Bank of England Staff Working Paper No. 594, 3. It is argued that although NPL is generally
} 
In the aftermath of the crisis, it has been suggested that provisioning be more forward-looking and that, in retrospect, had credit events been recognized before they occurred, might have made banks better prepared for losses when they were realized. ${ }^{9}$ However, the inherent pro-cyclicality of loan performance expectations by banks would probably have meant that credit institutions would have underestimated risk of instability. The current regulatory approach to NPLs definition gives firms a high degree of discretion and the practical implementation of rules depends much on effective enforcement. ${ }^{10}$ In terms of prudential regime of NPLs, the main problem is the lack of a harmonized framework to assess the obligors' ability to repay and whether it has become non-performing. ${ }^{11}$ Various factors affect the assessment of asset quality, namely (1) whether collateral, guarantees and other forms of security are factored into the asset quality classification; (2) whether the full outstanding value or only part of a loan is reported as non-performing; and (3) how to treat restructured loans. ${ }^{12}$

While policy makers and legislators in recent years focused in creating a standard classification of sources of banks' funding (i.e. equity and debt), scant attention has been given to creating a common identification of the asset quality. This chapter examines the supervision of NPLs taking into consideration the architecture of SSM and the role of ECB to manage and address the risks of unexpected deterioration of asset quality. The new supervisory tools introduced in the EBU aim to reduce the risk of failure of NPLs that can produce a serious impact in failing financial institutions. This chapter argues that the toolkit of supervisory measures established by the ECB - such as the provisioning backstop for deteriorated exposures - represents the new landscape of NPLs prudential regime.

The next section discusses the normative framework of NPLs in light of the recent initiatives adopted at the international level to resolve the negative impact on lending to the banking sector. Section three analyses the architecture of SSM and the role of ECB

\footnotetext{
defined as a loan that is more than 90 days past due, different definitions remain among central banks and credit institutions.

${ }^{9}$ See Samuel Knott, Peter Richardson, Katie Rismanchi and Kallol Sen, 'Understanding the fair value of banks' loans', (2014), Bank of England Financial Stability Paper No. 31, 7, available at https://www.bankofengland.co.uk/-/media/boe/files/financial-stability-paper/2014/understanding-thefair-value-of-banks-loans.

${ }^{10}$ Regulators are primarily concerned to think about NPLs in comparison (as a ratio) of loan loss reserves/capital (the 'Texas ratio').

${ }^{11}$ See David Bholat et al, 'Non-performing loans at the dawn of IFRS 9: regulatory and accounting treatment of asset quality', (2017), 18 Journal of Banking Regulation, 33-4.

${ }^{12}$ See Bholat et al, supra note 8.
} 
in relation to the NPLs issue taking into account the new regulatory mechanisms to monitor the classification of non-performing exposures (NPEs). Section four focuses on the supervisory actions of European Banking Authority (EBA) and the developments of accounting standard. Section five is devoted to examine the resolution and restructuring options for NPLs recovery. In this context, the objectives of reducing the intervention of public authorities and European financial institutions in failing banks constitute a challenge for regulators and market actors. The last section provides some conclusive observations.

\section{The regulatory definition of NPLs}

The definition of bank capital under Basel rules has marked a notable achievement in the assessment of loan quality although less attention has been made on harmonizing the classification of asset in the balance sheet. ${ }^{13}$ The lack of a common level playing field for NPLs makes meaningful comparison of banks' assets difficult for investors and regulators. The UN System of National Accounts provides a global statistical definition of NPLs as "a loan is non-performing when payments of interest or principal are past due by 90 days or more, or interest payments equal to 90 days or more have been capitalized, refinanced, or delayed by agreement, or payments are less than 90 days overdue, but there are other good reasons (such as a debtor filing for bankruptcy) to doubt that payments will be made in full". ${ }^{14}$

The Basel Committee on Banking Supervision (BCBS) published guidelines in evaluating credit risk for regulatory purposes. ${ }^{15}$ Under the Basel II capital framework, the internal ratings-based (IRB) approach required credit firms to provide own estimations of probability of default, loss given default and exposure at default. ${ }^{16}$ Default is defined as where an obligor is 90 days past due, or is unlikely to pay its credit

\footnotetext{
${ }^{13}$ The definition of capital was first harmonized under the Basel I Accord of 1988 through a soft law instrument. See Basel Committee on Banking Supervision, 'Report on International Convergence of Capital Measurement and Capital Standards', (1988), available at https://www.bis.org/publ/bcbsc111.pdf.

${ }^{14}$ See United Nations, United Nations System of National Accounts, (2008), available at https://unstats.un.org/unsd/nationalaccount/sna2008.asp. However the UN statistical definition of a non-performing loan leaves scope for firm discretion since the meaning of certain terms such as "objective evidence of impairment" are not precisely defined.

${ }^{15}$ See Basel Committee on Banking Supervision, 'Sound Practices for Loan Accounting and Disclosure', (1999), Basel Committee on Banking Supervision Paper, 35, para 91.

${ }^{16}$ See Basel Committee on Banking Supervision, 'International Convergence of Capital Measurement and Capital Standards', (2004), Revised Framework.
} 
obligations to the banking group in full, without recourse by the bank to actions such as realizing security. In 2006 the BCBS issued guidance that mentioned loan classification recommending banks to implement asset quality system on the basis of credit risk. ${ }^{17}$

Recently the BCBS provided guidelines on prudential treatment of problem assets aiming to set a common definition for the terms 'non-performing loan' and 'forbearance'. ${ }^{18}$ The definition in this document applies to all credit exposures from onbalance sheet loans, including debt securities, and off-balance sheet items, such as loan commitments and financial guarantees. The classification of non-performing developed for this purpose combines three existing concepts. Firstly, all exposures defined as in default under the Basel definition are considered non-performing. Secondly, exposures determined to be impaired for accounting purposes are defined as non-performing. Thirdly, loans that are past due by 90 days or where it is determined that full repayment is unlikely ${ }^{19}$ are also considered non-performing.

The BCBS clarifies that collateralization does not influence past due status and should not be considered in the categorization of NPEs. ${ }^{20}$ In addition, forbearance is defined as "a concession granted by a bank to a counterparty for reasons of financial difficulties that would not be otherwise considered by the lender". ${ }^{21}$ Basically forbearance comprises concessions extended to any exposures in the form of a loan, a debt security or an off-balance-sheet item due to the position of the counterparty. This definition covers exposures of performing and non-performing status before the granting of forbearance measures. The main purpose is to ensure a common approach to

\footnotetext{
${ }^{17}$ See Basel Committee on Banking Supervision, 'Sound credit risk assessment and valuation for loans', (2006), available at https://www.bis.org/publ/bcbs126.pdf. In a further Consultative Document issued in December 2014 on revisions to the standardized approach for credit risk, the Basel Committee on Banking Supervision suggested a definition of non-performing, whose threshold includes (amongst other criteria) 90 days past due for loans, and 30 days past due for securities. The purpose of these criteria is to calculate a 'Non-Performing Asset' (NPA) ratio when assessing exposures to other banks. At the time of issue, the proposals in this consultation were described by the BCBS as "at an early stage of development".

18 These new definitions are intended to complement existing accounting and regulatory measures, and as reference points to promote comparability. See Basel Committee on Banking Supervision, 'Prudential treatment of problem assets - definitions of non-performing exposures and forbearance', (2017), Guidelines, available at http://www.bis.org/bcbs/publ/d403.htm.

${ }^{19}$ This is similar to the definition developed by the EBA, Final draft implementing technical standards (ITS) on supervisory reporting on forbearance and non performing exposures under Article 99(4) of Regulation (EU) No 575/2013, EBA/ITS/2013/03/rev1.

${ }^{20}$ The Basel Committee on Banking Supervision also notes that non-performing status should be applied at the level of the counterparty in the case of exposures to a non-retail counterparty, and at the level of each exposure in the case of exposures to a retail counterparty.

${ }^{21}$ See Basel Committee on Banking Supervision, supra note 18, 7.
} 
the disclosure of modified loans and debt securities due to the case of borrower's financial difficulties. ${ }^{22}$

NPLs have become a recurrent phenomenon in some financial institutions and have dragged on economic activity, especially for countries that rely mainly on bank financing, as is the case in the euro area. ${ }^{23}$ In this context, countries such as Italy and Greece registered a sharp rise of NPLs and large losses among national banks. ${ }^{24}$ The Italian banking sector reported an outstanding stock of $€ 151$ billion of net NPLs (and EUR 324 billion of gross NPLs) mostly accumulated during the financial and sovereign debt crisis. ${ }^{25}$ The deterioration of past-due loans has been accompanied by the negative performance of some Italian banks' portfolio such as Unicredit, Banca Monte dei Paschi di Siena, Banca Popolare di Vicenza and Veneto Banca. ${ }^{26}$ The non-performing assets have triggered a sell-off of shares in these banks (halving their value) on concerns about their huge exposure to NPLs, resulting in low profitability. ${ }^{27}$ The IMF considers the turmoil of Italian banks to be among the leading potential risks to global growth.

\footnotetext{
${ }^{22}$ The Basel Committee on Banking Supervision recommends banks not to use forbearance practices to avoid classifying loans as non-performing.

${ }^{23}$ See International Monetary Fund, ‘A Strategy for Resolving Europe’s Problem Loans', (2015), Staff Discussion Note, SDN/15/19 9, available at https://www.imf.org/external/pubs/ft/sdn/2015/sdn1519.pdf.

${ }^{24}$ See EBA, 'Risk Dashboard. Data as of Q4 2016', (2017), 30, available at: http://www.eba.europa.eu/documents/10180/1804996/EBA+Dashboard+-+Q4+2016.pdf/74c92eb43083-47fc-bd5d-6a8ac64e8393.

${ }^{25}$ See Bank of Italy, 'Financial Stability Report', November 2017, n. 2, 25. It is underlined that the coverage ratio-provisions in relation to the whole stock of NPLs-reached 53.5 per cent. 26 Ibid, 18.

${ }^{27}$ On December 2016, the Italian government passed the Law Decree No 237/2016 - converted into Law No 15/2017. The Law Decree No 237 of 2016 'Urgent measures for the protection of savings in the banking sector' provides guarantees for the public support of banks under liquidity and capital stress scenario. The Decree provides public financial assistance to manage banking crises and consists of liquidity support measures and public recapitalization measures. Liquidity measures are guarantees granted by the State on liabilities issued after the decree law's entry into force, aiming to facilitate the bank's ability to restore its own viability. The Law Decree requires that only shareholders and holders of hybrid and subordinated bank bonds are involved in the burden sharing, the main aim is to avoid the involvement of the bank's non-subordinated creditors under the bail-in rules. Bank's shareholders accept (1) the dilution of their shares following the State's intervention; and (2) the conversion into equity of the subordinated bonds. Holders of hybrid and subordinated instruments accept the conversion into equity of these instruments, in whole or in part, as necessary. In addition, the Law Decree establishes a compensation mechanism to protect retail investors who will receive new shares following the burden sharing. Under the Law Decree, the access to public support is limited to banks that are not failing or likely to fail, but to banks that need to strengthen capital in case of the crisis or adverse scenario. The Ministry of Economy and Finance (MEF) may intervene to purchase these shares and in exchange, investors will receive ordinary bonds from the bank (issued at par by the bank or a company that is part of the same group) for a value equal to the amount paid by the MEF for the purchase of the shares. The compensation scheme can be accessed under limited circumstances: (1) compensation may only be provided to retail investors, not qualified or professional investors; and (2) the MEF may intervene in support of a settlement agreement between a bank and these investors to avoid or resolve a dispute concerning the selling of converted instruments.
} 
Jassaud and Kang have estimated that the NPL ratio in Italy in 2014 was 17 percent of all loans. ${ }^{28}$ High percentages of NPLs reduce profitability, increase funding costs and tie up bank capital, which negatively impact credit supply and ultimately growth. ${ }^{29}$ Addressing the rise of NPLs has become a key concern for the EU banking system and the supervision of NPLs requires comprehensive action to deal with these types of bad loans sitting on banks' books. ${ }^{30}$

\subsection{The treatment of loan loss provisioning}

The initiatives to harmonize NPL definition and asset classification for purposes of loan loss provisioning (LLP) require considerable monitoring of the prudential regulator: the quality of the data for the purpose of assessing loans in distress represents the main question for bank supervisors. ${ }^{31}$ The debate about the link between LLP and bank capitalization shows the relevance of provisioning powers to ensure that loans are capital-neutral. The conventional view - and the rationale for imposing capital requirements on banks - is that LLPs and related capital deductions are meant to support banks deal with expected losses from their lending business, while bank capital is meant to provide buffers for unexpected losses. ${ }^{32}$

While higher ex-ante provisioning against expected loan losses lowers bank profitability in the short term, over the long term the progressive constitution of LLPs in good times reduces the chances of having a situation in crisis times where ex-post NPL losses force a bank to raise capital. Borio et al. ${ }^{33}$ and Laeven and Majnoni ${ }^{34}$ argued that LLPs need to be an integral component of banking regulation because they act as forward-looking provisioning and timely recognition of loss. The key economic consequence of

\footnotetext{
${ }^{28}$ See Nadege Jassaud \& Kenneth Kang, 'A Strategy for Developing a Market for Nonperforming Loans in Italy', (2015), IMF Working Paper No. 15-24. Jassaud and Kang also cite a lack of tax rebates on losses in Italy, and that the current accounting standard in Europe (IAS 39) is not explicit on exactly when and how to write off uncollectible loans.

${ }^{29}$ Ibid, 10.

${ }^{30}$ See Bholat et al, supra note 8,9 .

${ }^{31}$ See Mark Wahrenburg, 'Provisioning policies for non-performing loans: How to best ensure a "clean balance sheet”?', (2017), White Paper Series, No. 51, 5-6, available at https://www.econstor.eu/handle/10419/171930.

${ }^{32}$ See paras 12, 13 and 17 in the Basel II agreement that indicate the methodology of computation of LLPs: current accounting under IFRS and US GAAP requires LLPs to reflect incurred losses that means losses that a bank estimates it has already suffered on a loan, instead of the future losses it expects to suffer.

${ }^{33}$ See Claudio Borio, Craig Furfine \& Philip Lowe, 'Procyclicality of the financial system and financial stability: issues and policy options’, (2001), BIS papers 1, 1-2.

${ }^{34}$ See Luc Laeven \& Giovanni Majnoni, 'Loan loss provisioning and economic slowdowns: too much, too late?', (2003), 12(2) Journal of Financial Intermediation, 178-9.
} 
insufficient LLP and the persistence of NPLs on bank balance sheets is the combined threat of a 'capital crunch' and a 'credit crunch.' In this context, the Japanese 'lost decades' and the recent global financial crisis provide valid cases. ${ }^{35}$

\section{The SSM and the role of ECB}

The EBU has favoured the centralization of bank supervision and resolution: this architecture within its respective mandate should be able to efficiently deal with the proliferation of cross-border banking and any possible negative implications. The ECB is the competent authority responsible for supervising (significant) credit institutions established in the Euro area, while NPL of non-credit institutions are supervised by other authorities, namely the European Commission, the EBA and the National Competent Authorities. The SSM has introduced a set of supervisory tools to assess the banks' balance sheet through on site-inspections, stress test and asset quality reviews. ${ }^{36}$ The ECB established a prudential regime to strengthen the capital rules and banking supervision since NPLs represent the major systemic threat that they are facing as they may rapidly lead to bank and borrower insolvencies. ${ }^{37}$ In terms of supervisory powers, Article 16(2) of the SSM Regulation provides that the ECB can apply 'specific

\footnotetext{
${ }^{35}$ See Ricardo J. Caballero, Takeo Hoshi \& Anil K. Kashyap, 'Zombie lending and depressed restructuring in Japan', (2008), 98(5) American Economic Review, 1943-44.

${ }^{36}$ See ECB, 'Stocktake of national supervisory practices and legal frameworks related to NPLs', (2017), 3-4,

available at https://www.bankingsupervision.europa.eu/ecb/pub/pdf/ssm.stock_taking2017.en.pdf. Stress tests are indicators that assess the financial stability of banks. The test examines the three-year period following a recent reference date and includes a baseline macroeconomic scenario together with the adverse scenario, which assumes the impact of one or more particularly severe shocks. The European stress tests are coordinated by the EBA that regulates the stress test exercise under the direct supervision of ECB. The stress test is designed as an informative element relevant for the supervision process. The results will then be used by the competent authorities to assess the capacity of a bank to meet the regulatory requirements in stressed scenarios on the basis of common methodologies and assumptions.

${ }^{37}$ The question of asset quality classification has become prominent since the divergence in practice between firms and regulators in defining "non-performing" has hampered the need for NPL harmonization. Within the NPL category are comprised: (1) bad loans; (2) default loans; and (3) distressed debt. The classification depends on several factors and varies across jurisdictions. In some countries, nonperforming means that the loan is impaired while in others can mean that payments are past due. Nevertheless, a rather common feature of nonperforming loans appears to be that a payment is "more than 90 days" past due, especially for retail loans'. The classification of the loan as nonperforming by the bank and when the loan becomes "bad debt" depends on domestic regulations. Further, the rising discrepancy between banks' overdue loan ratios and NPL ratios makes difficult to identify deteriorated loans that are not formally classified as nonperforming. This problem is particularly evident in the Chinese banks where the fragility of loan loss provisions does not help to mitigate the NPL classification issue. See Yuan Yang, 'China banks in stand-off with regulators on loan loss provisions', Financial Times, London, 30 October 2016.
} 
provisioning policy or treatment of assets in terms of own funds requirements ${ }^{38}$. These supervisory actions consist in requiring credit institutions (1) to hold additional layers of funds in excess of the capital requirements to cover unexpected losses; (2) to set strategies and internal mechanisms to foster compliance with supervisory requirements; (3) to implement specific provisioning policy to reduce excessive exposures and systemic risk transactions; and (4) to enhance information disclosure on remuneration policies, profits distribution and liquidity requirements.

In March 2017 the ECB produced a qualitative guidance on non-performing loans, including consideration of how the 'unlikely to pay' criterion should be applied in practice, and how banks should manage and monitor forbearance, write offs and collateral valuation. ${ }^{39}$ This supervisory toolkit aims to address the issue of identification and allocation of deteriorated loans in the EU banking sector. ${ }^{40}$

The ECB clearly stated in the guidance on NPLs that the priority is to develop workout units and private debt restructuring agreements to write-off bad loans from the bank balance sheet. ${ }^{41}$ This should stop Member States to provide financial assistance in support of their banks to cover unexpected losses due by failures to repay on time certain business transactions. ${ }^{42}$ The NPL guidelines are not intended to introduce standards on resolution scenarios, but rather on the solution of NPL problems in SSM banks well ahead of the failing or likely to fail threshold. These provisions are directed to implement a prudential supervisory regime of NPLs through best practices such as operational plans and internal controls to prevent the risk of asset deterioration. As indicated in the guidance, 'the key objective of granting forbearance measures is to pave the way for nonperforming borrowers to exit their non-performing status, or to prevent

\footnotetext{
${ }^{38}$ See Article 16(2) of Council Regulation (EU) No 1024/2013, supra note 1.

${ }^{39}$ See ECB, 'Guidance to banks on non-performing loans', (2017), 49-50, available at https://www.bankingsupervision.europa.eu/ecb/pub/pdf/guidance_on_npl.en.pdf.

${ }^{40}$ It can be noted that in the south of the European Continent, the European Bank Coordination 'Vienna Initiative'- a private-public sector forum which brings together international financial institutions, international organizations, public authorities and private banks - has launched various proposals to address NPLs in CESEE countries. The main purpose is to create a platform of coordination and cooperation for Western banks to enhance enforcement measures, improving consistency in the definition of NPLs and removing legal obstacles and execution issues in distressed transactions. Specifically, the 'Vienna Initiative' has adopted a set of principles for monitoring and preventing the deterioration of assets.

${ }^{41}$ See ECB, supra note 36, 19-20.

${ }^{42}$ See the controversial cases of State aid of Alpha Bank, Eurobank and Piraeus Bank in European Commission, 'State aid: Commission approves amended restructuring plans for Alpha Bank and Eurobank' IP/15/6184, 26 November 2015; and, 'State aid: Commission approves aid for Piraeus Bank on the basis of an amended restructuring plan', (2015), IP/15/6193.
} 
performing borrowers from reaching a non-performing status' ${ }^{43}$ The guidance aims to harmonize private mechanisms to resolve troubled banks through the mandatory implementation of the NPL guidance into the complex system of banking resolution. ${ }^{44}$

The NPL guidance has been further developed in the prudential treatment for distressed loans through supervisory expectations on the classification of NPEs. ${ }^{45}$ The ECB's supervisory expectations supplement the NPL guidance by specifying the regulatory actions when assessing a bank's levels of prudential provisions for NPEs. Specifically, the ECB will assess banks' practices and report any divergences with the prudential provisioning expectations: banks are required to maintain their level of monitoring in line with the prudential expectations. Supervisory expectations on secured exposures - that benefit from credit risk protection - apply after seven years from the date on which they have been classified non-performing (e.g. "vintage period"). Supervisory expectations on unsecured exposures - that do not benefit from credit risk protection - apply after two years from the date on which they have been defined as "vintage". The ECB is responsible to assess the exposure level of assets and disclose information in a continue supervisory dialogue, taking into account 'a linear path starting from year three onwards'. ${ }^{46}$ It can be noted that the ECB's supervisory expectations are directed to monitor the lifecycle of NPEs with limited provision coverage, and they apply only to new NPLs as of April 2018. ${ }^{47}$ The NPL guidance represents a welcome improvement in the regulatory framework of asset classification since with the advent of the EBU the ECB is in charge of the supervision of significant credit institutions.

\subsection{The ECB prudential regime on NPEs}

The implementation of bank's levels of prudential provisions for NPEs has raised particular attention in the monitoring practices of the ECB: the new regulatory tools to

\footnotetext{
${ }^{43}$ See ECB, supra note $36,39$.

${ }^{44}$ However, the guidelines are soft law recommendations — not binding and not enforceable — and leave discretion to national authorities to implement them at the domestic level.

${ }^{45}$ See ECB, 'Addendum to the ECB Guidance to banks on nonperforming loans: Prudential provisioning backstop for non-performing exposures', (2018), 2, available at https://www.bankingsupervision.europa.eu/ecb/pub/pdf/ssm.npl_addendum_201803.en.pdf. ${ }^{46} \mathrm{Ibid}, 11$, where it is stated that 'the ECB considers that prudent provisioning implies the continuation of booking accounting provisions in line with banks' assessments and existing accounting principles'.

${ }^{47}$ The addendum clarifies that " "new NPEs" are all those exposures that are reclassified from performing to non-performing in line with the EBA's definition after 1 April 2018, irrespective of their classification at any moment prior to that date'. See ECB, supra note 45,7 .
} 
oversight "vintage" NPLs and related collateral seek to intensify standardization and supervisory convergence. On this view, the ECB risk-reduction measures on NPEs aim to reduce national supervisory discretion and heterogeneity on loan classification. It can be observed that the prudential provisioning expectations complement the 'Guidelines on supervisory review and evaluation process' (SREP) set by the EBA to oversight the asset quality and capital coverage of banks. ${ }^{48}$ It is worth mentioning that the SREP framework provides recommendations on how to assess the components of risk profile of the credit institutions, namely internal governance, liquidity requirements and capital adequacy ratio. This supervisory process is designed to identify common methodologies for restoring the viability of banks in crisis. The EBA Guidelines indicate operating models and management strategies to evaluate the risks of individual banks.

Specifically the SREP regime provides key indicators for the monitoring of institutions such as: (1) the business model analysis; (2) the assessment of internal governance and institution-wide controls; (3) the assessment of risks to capital (i.e. capital adequacy evaluation); and (4) assessment of risks to liquidity and funding (i.e. liquidity adequacy evaluation). ${ }^{49}$ According to the SREP assessment, competent authorities identify the vulnerability of banks' balance sheet through quantitative capital measures, quantitative liquidity measures and other supervisory measures including early intervention. These methodologies apply to banking activities and risks in a forward-looking manner to reflect stronger correlation between risk profile of institutions and capital requirements. ${ }^{50}$ In the SREP criteria, particular relevance is placed on the assessment of the portfolio credit quality that set the oversight of forborne and NPEs. Competent authorities are responsible to monitor the non-performing rates, the distribution of the exposures, the foreclosed assets and the "vintage" NPL portfolio. ${ }^{51}$ The business models and credit risk indicators of the SREP respond to the regulatory instances of timely classification of non-performing assets. It can be argued that the SREP process is a valuable indicator for understanding the internal management of credit institutions since 'the SREP sets out where a bank stands in terms of capital requirements and the way it

\footnotetext{
${ }^{48}$ See EBA, 'Guidelines on common procedures and methodologies for the supervisory review and evaluation process (SREP)', EBA/GL/2014/13, 19 December 2014, available at https://www.eba.europa.eu/documents/10180/935249/EBA-GL-2014$13+($ Guidelines+on+SREP+methodologies+and+processes).pdf.

${ }^{49}$ Ibid, 21.

${ }^{50}$ See ECB, 'SSM SREP Methodology Booklet', 2017 edn, 46, available at http://financialstability.org/wp-content/uploads/2016/03/2016-3_ecb_ssm-srep-methodology-booklet.pdf.

${ }^{51}$ See EBA, supra note 48, 71.
} 
deals with risks' ${ }^{52}$ In this context, the ECB prudential regime on NPEs - developed with the supervisory expectations on "vintage" NPLs - can have a positive impact on the SREP in terms of coordination among various risk-reduction measures. It is evident that these reforms aim to avoid discrepancies across supervisory actions and foster operational harmonization in the Banking Union. ${ }^{53}$ As noted, 'the effort to harmonize NPL definitions and provisioning rules needs to be complemented by intrusive supervision, including regular independent asset quality reviews, effective usage of supervisory powers to ensure adequate provisioning and write-off for outstanding NPLs'. ${ }^{54}$ On this view, the ECB's supervisory expectations seem the way forward to achieve sound level of credit protection for the non-performing exposures. This continued strengthening of prudential regulation will have significant effect for supervisory convergence and bank stability. However the standardization process of NPLs treatment will require supervisors to maintain ongoing dialogue among competent authorities and ensure greater operational harmonization.

\section{The supervisory actions of EBA and accounting standards}

The fact that the ECB shall also take into account the supervisory action of the EBA can be considered a convergent regulatory response to the issue of the reporting of nonperforming loans and forbearance. ${ }^{55}$ The EBA document standardizes the definition of "exposure", "non-performing exposures" and "forborne exposures". ${ }^{56}$ The EBA standards define non-performing as loan of either 90 days past due, or where the debtor is unlikely to pay its credit obligations in full. The European Securities and Markets Authority (ESMA) has noted that disclosures about forbearance practices in the financial statements diverged significantly and were often limited in the amount of information provided and vague as to content. ${ }^{57}$ In this context, the EBA has published

\footnotetext{
${ }^{52}$ See Edouard Fernandez-Bollo, 'Inside Perspective: The ACPR's View on the Operational Functioning of the Banking Union', (2017), 18(3) European Business Organization Law Review, 428.

${ }^{53}$ See Laura Noonan, 'ECB finds big differences in how eurozone deals with NPLs', Financial Times, London, 12 September 2016.

${ }^{54}$ See Nadege Jassaud \& Edouard Vidon, 'European NPLs through the crisis: A policy review', (2017), 25(4) Journal of Financial Regulation \& Compliance, 420.

${ }^{55}$ See EBA, supra note 19.

${ }^{56}$ Ibid, para 149, which states that for the purpose of template 18, "exposures" include all debt instruments (loans, advances and debt securities) and off-balance sheet exposures (loan commitments, financial guarantees and other revocable and irrevocable commitments) excluding trading exposures and off balance sheet exposures except held for trading exposures.

${ }^{57}$ See ESMA, 'Treatment of Forbearance Practices in IFRS Financial Statements of Financial Institutions', (2012), ESMA/2012/853,
} 
a set of guidelines on banks' credit risk management implementing the accounting standard for expected credit losses and the prudential requirements for NPLs. ${ }^{58}$

Following the 2007-09 global crisis, the G20 called for accounting standard setters to "strengthen accounting recognition of loan-loss provisions by incorporating a broader range of credit information". ${ }^{59}$ The FSB echoed the G20 recommendations encouraging standards that "will incorporate a broader range of available credit information than existing provisioning requirements, so as to recognise credit losses in loan portfolios at an earlier stage". ${ }^{60}$ Under the International Financial Reporting Standards (IFRS) and the generally accepted accounting principles (GAAP) impairment was only recognized when a loss event had occurred.

During the financial crisis banks often did not disclose the level of write offs, situations where both a loan and the related provision are derecognized from the balance sheet because there is no realistic prospect of recovery. The assessment of whether a write-off is required inevitably involves judgement on the part of the bank, and so it follows that one bank might elect to write off an asset where another bank would not, even when the underlying economics are broadly similar. In terms of asset quality, provisions and write offs, regulatory definitions are divergent.

Under the International Accounting Standards Board (IASB) approach, the forwardlooking provision is set at 12 months of expected loss for all loans, and full expected loss over the lifetime of a loan where 'significant increase in credit risk' has occurred. When determining whether such credit deterioration has taken place, the accounting guidance makes reference to an internal credit downgrade as an indicator, thus assuming that an internal credit classification might exist. The debate on accounting standards sheds light on the different views between securities and banking regulators about the appropriate allowance for managerial judgement and discretion in the estimation of future losses. ${ }^{61}$

\footnotetext{
available at https://www.esma.europa.eu/sites/default/files/library/2015/11/2012-853.pdf.

${ }^{58}$ See EBA, 'Guidelines on credit institutions' credit risk management practices and accounting for expected credit losses', (2017), Final Report EBA/GL/2017/06 available at https://www.eba.europa.eu/documents/10180/1842525/Final+Guidelines+on+Accounting+for+Expecte d+Credit+Losses+\%28EBA-GL-2017-06\%29.pdf.

${ }^{59}$ See G20 Research Group, 'Declaration on Strengthening the Financial System', (2009) Global Plan Annex, available at http://www.g20.utoronto.ca/2009/2009ifi.pdf.

${ }^{60}$ See Financial Stability Board, 'Improving Financial Regulation', (2009), Report of the Financial Stability Board to G20 Leaders, available at http://www.fsb.org/wp-content/uploads/r_090925b.pdf. ${ }^{61}$ See Basel Committee on Banking Supervision, 'Basel 3: A global regulatory framework for more resilient banks and banking systems', (2011), available at https://www.bis.org/publ/bcbs189.pdf. This
} 
Banking regulators argue that early provisioning provides a buffer against potential future losses. ${ }^{62}$ On the other hand, securities regulators have been wary of banks raising high provisions and then releasing them as a means of artificially smoothing profits in order to reduce the volatility of their stock market valuations, a typical approach of the 'incurred loss' model. ${ }^{63}$ It can be observed that the steps being taken post crisis, to bring in greater forward looking LLPs, will increasingly integrate the accounting standards on provisioning with information useful to prudential regulators in assessing capital adequacy requirements.

\section{Restructuring and resolution options for NPLs recovery beyond the SSM}

The ECB NPL policy is alone non-sufficient to reduce NPLs but other measures are needed. Various proposals to restructure NPLs have been advanced, namely individual bank restructurings, bank-internal bad-bank units and bank-specific asset management companies (AMCs). ${ }^{64}$ Enria suggested establishing an AMC with government support to resolve NPLs selling the assets at their economic value. ${ }^{65}$ Avgouleas and Goodhart proposed a new structure for a Pan-European "bad bank" with virtually ringfenced country subsidiaries to ensure burden sharing without debt mutualisation. ${ }^{66}$ This proposal has been echoed in the 2018 Commission blueprint on national $\mathrm{AMC}^{67}$ : the document provides non-binding principles to guide Member States in the implementation of AMCs at the domestic level. These principles highlight the role of AMC in removing troubled assets from banks' balance sheets and restructuring banks

\footnotetext{
document has been revised by the paper 'Basel III: Finalising post-crisis reforms', (2017), available at https://www.bis.org/bcbs/publ/d424.pdf.

${ }^{62}$ See Kees Camfferman, 'The Emergence of the 'Incurred-Loss' Model for Credit Losses in IAS 39', (2015), 12 Accounting in Europe, 2.

${ }^{63}$ See Anne Beatty \& Scott Liao, 'Do delays in expected loss recognition affect banks' willingness to lend?’, (2011), 52 Journal of Accounting and Economics, 1-2.

${ }^{64}$ See Patrizia Baudino \& Hyuncheol Yun, 'Resolution of non-performing loans - policy options', (2017), FSI Insights on policy implementation No, 3 3-4, available at https://www.bis.org/fsi/publ/insights3.pdf.

${ }^{65}$ See Andrea Enria, 'The EU banking sector - risks and recovery. A single market perspective', Luxembourg, (2017), 16, available at https://www.esm.europa.eu/speeches-and-presentations/esmseminar-andrea-enria-eba-chairperson.

${ }^{66}$ See Emilios Avgouleas \& Charles Goodhart, 'Utilizing AMCs to tackle Eurozone's legacy non performing loans', (2017), European Economy Banks, Regulation, and the Real Sector, 103-4, available at http://european-economy.eu/wp-content/uploads/2017/07/EE_1.2017.pdf.

${ }^{67}$ See European Commission, 'AMC Blueprint. Accompanying the document Communication from the Commission to the European Parliament, the European Council, the Council and the European Central Bank. Second Progress Report on the Reduction of Non-Performing Loans in Europe', Commission Staff Working Document, Brussels, SWD(2018) 72 final, available at http://ec.europa.eu/finance/docs/policy/180314-staff-working-document-non-performing-loans_en.pdf.
} 
with high levels of NPLs. It is stated that 'AMCs can be private or (partly) publicly funded without State aid, if the State can be considered to act as any other economic agent' ${ }^{68}$ The blueprint underlines the need to complement the AMCs with the State aid rules, the Bank Recovery and Resolution Directive (BRRD) and the Single Resolution Mechanism regime to create a common level playing field of rules on NPLs resolving mechanism.

The distressed loans problem implies allocating losses within the system, particularly losses that should be borne either by banks' customers, banks themselves, investors or States. ${ }^{69}$ The fact that there is no universal definition of NPL - as a sum of borrowed money upon which the debtor has not made his or her scheduled payments for at least 90 days - creates difficulty to assess the viable option to restructure deteriorated assets. $^{70}$ The available options for NPLs recovery are currently work in progress and need to be fully tested. ${ }^{71}$ In this context, NPL provisioning treatment is still not sufficient in the absence of harmonized deposit insurance. It can be noted that State level deposit insurers are not viable inside a monetary union because the liquidation of small banks could overwhelm the capacity of national deposit insurance. Mutualization of deposit insurance requires full harmonization of insolvency laws because the effectiveness of the bank liquidation process will have an impact on the financial situation of the deposit insurance over which insured depositors have a legal claim.

Converging towards a harmonized approach on recovery and resolution plans for NPLs is the question at stake. ${ }^{72}$ As observed, 'given that the barriers to cross-border banking are likely to fall, the EU should consider what sort of banking structure would provide the best combination of an integrated financial system and a financial system in which the banks are neither too large to supervise nor too large to safely fail' ${ }^{73}$ This means that EU rules will have impact on where banks shed operations due to cost

\footnotetext{
${ }^{68}$ Ibid, 4.

${ }^{69}$ See Benoit Mesnard, Alienor Anne Claire Duvillet-Margerit, Cairen Power \& Marcel Magnus, 'Nonperforming loans in the Banking Union: stocktaking and challenges', (2016), European Parliament, 4, available at http://www.europarl.europa.eu/RegData/etudes/BRIE/2016/574400/IPOL_BRI(2016)574400_EN.pdf

${ }^{70}$ See Luis Cortavarria, Claudia Dziobek, Akihiro Kanaya \& Inwon Song, 'Loan Review, Provisioning, and Macroeconomic Linkages’, (2000), IMF Working Paper No. 00/195, 11-12.

${ }^{71}$ See Faidon Kalfaoglou, 'NPLs resolution regimes: Challenges for regulatory authorities' (2018), 11(2), Journal of Risk Management in Financial Institutions, 175-6.

${ }^{72}$ See Vitor Constâncio, 'Resolving Europe's NPL burden: challenges and benefits', Keynote speech at the event 'Tackling Europe's non-performing loans crisis: restructuring debt, reviving growth', (2017), available at https://www.ecb.europa.eu/press/key/date/2017/html/sp170203.en.html.

${ }^{73}$ See Nieto and Wall, supra note 3, 21.
} 
factors of maintaining operations and risk will likely migrate to less regulated local entities in a risk race to bottom. Barriers to the resolution of problem loans such as legal or economic impediments to collateral realization may also result in the inability or unwillingness of banks to write loans off in a timely manner. This can result in a higher number of highly-provisioned loans remaining on these banks' balance sheets.

An example of effective and timely resolution options for NPLs is found in the Italian piece of legislation (Law No 132/2015) ${ }^{74}$, amending the procedures for firms' liquidation and restructuring of assets. This new law aims to increase the speed and efficiency of insolvency procedures and property foreclosures, and to promote higher recovery rates for creditors. Another legislative initiative concerning NPLs recovery (i.e. non-possessory pledge and foreclosure of collateral) has been launched with the Italian insolvency law reform of $2016 .^{75}$ The legal framework introduced the possibility to set private enforcement clauses in loan contracts with firms, allowing creditors to take ownership of collateral out-of-court in case of a debtor's default. ${ }^{76}$

The out-of-court enforcement procedures for secured loans granted to enterprises amend the "pactum marcianum", according to which the creditor takes over or dispose the collateral but needs to compensate the debtor for any excess value of the collateral once the loan is satisfied. ${ }^{77}$ The new enforcement rules should reduce the court involvement and speed up the process of collecting bad assets: this would ease the agreement among creditors and enhance the marketability of NPLs. ${ }^{78}$ The law introduces provisions to facilitate access to finance for small and medium-sized enterprises (SMEs) enabling entrepreneurs to pledge movable assets while continuing to

\footnotetext{
${ }^{74}$ See Italian Law No 132/2015 published in Italian OJ No 192 of 20 August 2015 that converted the Law Decree No 83/2015 published in Italian OJ No 147 of 27 June 2015 available at: http://www.gazzettaufficiale.it/atto/serie_generale/caricaDettaglioAtto/originario?atto.dataPubblicazion eGazzetta=2015-08-

20\&atto.codiceRedazionale $=15 \mathrm{G} 00136 \&$ is Anonimo $=$ false $\&$ normativi $=$ true $\&$ tipoVigenza $=$ originario $\&$ tipoSerie $=$ serie_generale $\&$ currentPage $=1$.

${ }^{75}$ See Italian Law Decree No 59/2016 converted into Italian Law No 119/2016.

${ }^{76}$ See European Commission, 'Italy - Review of progress on policy measures relevant for the correction of Macroeconomic Imbalances', (2016), 13, available at: https://ec.europa.eu/info/files/italyreview-progress-policy-measures-relevant-correction-macroeconomic-imbalances-december-2016_en. 77 See José Garrido, 'Insolvency and Enforcement Reforms in Italy', (2016) IMF Working Papers, 8, available at: https://www.imf.org/external/pubs/ft/wp/2016/wp16134.pdf.

${ }^{78}$ The Italian Insolvency law provides both in-court and out-of-court restructuring tools. See Monica Marcucci, Alessandra Pischedda \& Vincenza Profeta, 'The changes of the Italian insolvency and foreclosure regulation adopted in 2015', (2015), Bank of Italy notes on Financial Stability and Supervision No. 2, 2. As observed, 'faster and more efficient insolvency and foreclosure procedures will have a twofold effect on the stock of NPLs. In the short term, they should reduce the discount required by NPL buyers, with positive effects on NPL prices and on the perspective of development of a market for these assets'.
} 
use them, and to enforce new non-possessory security interests over movable assets.

The main aim of these provisions is to enhance out-of-court restructuring agreements in view of a timely resolution of firm's crisis. This mechanism reflects the UK company law procedure of "scheme of arrangement" that allows the English court to sanction and give effect to an arrangement between a company and a class or classes of its creditors (or its shareholders). ${ }^{79}$

The Italian out-of-court proceeding allows creditors of a firm that has filed for "concordato preventivo" to submit the restructuring plans in competition with the one presented by the firm. ${ }^{80}$ These reforms can be considered a step forward in the resolution options to address bad loans, particularly in protecting creditors' interests to invest in distressed debts of viable firms and to pursue higher recovery rates. The rules on non-possessory pledge and foreclosure of collateral can have a systemic impact in the restructuring of troubled banks as they can create legal certainty and confidence in the process of divesting NPLs portfolio. As noted by the ECB, 'the Italian supervisory regulation for NPLs is mainly principles-based with regard to the guidelines issued to banks on NPLs management practices' ${ }^{81}$ On this view, the Italian government introduced a mechanism of double guarantees: the guarantee to collateralize liabilities and sell the senior tranches under the State backed-scheme 'GACS' 82 , and the guarantee

\footnotetext{
${ }^{79}$ English Companies Act 2006, part 26 regulates the procedure of scheme of arrangement. The English court can order that the terms of the scheme agreed by the requisite majority of a scheme class are binding on all the members of that scheme class. In other words, the requisite majority, with the English court's approval, can bind the minority into the amendments or compromise of those scheme class creditors' rights. The English legislation does not prescribe the terms or scope of the compromise or arrangement. An English scheme can be used to cut through documentary restrictions or voting majorities or thresholds under the documents in question, including when the contractual terms state that unanimous support is necessary. See, inter alia, Jennifer Payne, Schemes of arrangement. Theory, Structure and Operation (Cambridge University Press 2014), 1-2.

${ }^{80}$ Prior to the law reform, a firm filing for 'concordato preventivo' had the exclusive authority to submit a restructuring plan. The 'concordato preventivo' is an alternative procedure of the liquidation of enterprises, it allows creditors to participate actively in the sale of assets and, overall, in the reorganization process.

${ }^{81}$ See ECB, 'Stocktake of national supervisory practices and legal frameworks related to NPLs', September 2016, 87, available at https://www.bankingsupervision.europa.eu/legalframework/publiccons/pdf/npl/stock_taking.en.pdf. ${ }^{82}$ The Guarantee on Securitization of Bank Non Performing Loans (GACS) introduced by Italian Law Decree No 18/2016 (converted into Law No 49/2016) is an aid-free scheme aiming to assist Italian banks in securitizing and moving NPLs off their balance sheets. Basically, it is a State guarantee scheme open to all banks on a voluntary basis. The State guarantee consists in remunerating the senior notes at market terms according to the risk taken, i.e. in a manner acceptable for a private operator under market conditions. The Ministry of Economy and Finance (MEF) can issue a GACS guarantee to secure the payment obligations of Italian Special Purpose Vehicles (SPVs) in relation to senior tranches of asset-backed notes issued by the SPVs within the securitization transactions of NPLs according to the Italian securitization law No 130/1999. It can be observed that Italian Law No 49/2016 allows for the provision of State guarantees for NPLs securitization transactions that would contribute to alleviate the pressure on banks' balance sheets.
} 
to inject capital by purchasing shares. The State provides a double securitization: (1) on the credit enhancement of senior notes; and (2) on the collateralized losses of the junior bondholders. ${ }^{83}$ In other words, the government guarantee should favour the coverage of gap between the net book value and the market value of the NPLs with the aim to improve the trade of bad loans.

The solution adopted by the Italian regulatory authorities to address the NPLs issue is an improvement of the current legislative framework even if the guarantees mechanism seems an accounting makeup - as the losses cannot disappear - rather than a full definition of problems. The European Commission stated that 'the State guarantee on the senior tranche will only become effective, if at least more than half of the nonguaranteed and risk-bearing junior tranche has been successfully sold to private market participants'. ${ }^{84}$ The GACS system to resolve NPLs raises complex challenges linked to the market conditions: a restructuring mechanism that reflects a regulatory compromise where the guarantees could be activated at the expenses of taxpayers' money.

In this context, the EU Commission published a proposal for a directive on minimum procedures for out-of-court settlement regarding NPLs. ${ }^{85}$ This new proposal links the various supervisory initiatives taken by the SSM and EBA in addressing the NPLs issue. In managing NPLs, the proposal aims (1) to foster the debt recovery procedures through the implementation of a distinct common accelerated extrajudicial collateral enforcement procedure; and (2) to create secondary markets for NPLs. The overall objective is to reduce the burden of NPLs in the banks' balance sheet by introducing efficient out-of-court procedures to recover value from collateral and to lower the costs for resolving NPLs making them more competitive in the market. ${ }^{86}$

For resolution tools to work in practice, there needs to be a better understanding of what assets are worth in a crisis situation, and therefore of asset quality more generally. Adequate provisioning for NPLs requires overcoming complex strategic incentives that

\footnotetext{
${ }^{83}$ It can be noted that Italian law does not require the consent of the borrower for the sale of a loan, only the notification of the borrower. Article 58 of the Italian Banking Act (No 385/93) provides an exemption from the obligation to notify each debtor in the case of a bulk loan sale.

${ }^{84}$ See European Commission, 'State aid: Commission approves impaired asset management measures for banks in Hungary and Italy', IP/16/279, 10 February 2016, available at http://europa.eu/rapid/pressrelease_IP-16-279_en.htm.

${ }^{85}$ See European Commission, 'Proposal for a Directive of the European Parliament and of the Council on credit servicers, credit purchasers and the recovery of collateral', Brussels, COM(2018) 135 final, available at https://ec.europa.eu/info/law/better-regulation/initiatives/com-2018-135_en.

${ }^{86}$ See Alexander Lehmann, 'Risk reduction through Europe's distressed debt market', Bruegel Policy Contribution, Issue n. 02, 18 January 2018, 5-6, available at http://bruegel.org/wpcontent/uploads/2018/01/PC-02_2018-100118.pdf.
} 
banks have in either wanting to keep LLPs low, or for not writing NPLs off from their balance sheets. The timing of losses taken as a result of provisions or write offs and the level of LLPs set aside for future NPLs on the balance sheet are often part of a bank's strategy to smooth reported earnings and reported capitalization. ${ }^{87}$

\section{Concluding remarks}

NPLs constitute a real concern to the banking sector. They can produce a serious impact in the systemic credit institutions and in the fragile financial firms. To strengthen the balance sheet of banks non-performing exposures have to be restructured, something that regulators are not always ready to implement. To reduce the likelihood of authorities' intervention and increase the role of creditors, the process of resolution and restructuring of NPLs represents the potential challenges investors and policy makers may face. ${ }^{88}$ The growing of deteriorated loans poses an instance where the workings of the SSM and the supervisory regime of ECB have been put to the test. Moreover, the NPLs demonstrated that banks rely on government rescues and bailout programmes ${ }^{89}$ and it is difficult to predict a full implementation of the prudential treatment for asset classification. It can be argued that the ECB's supervisory practices are directed to strengthen the harmonization process of bank supervision and create sound prudential environment on NPLs with the Banking Union.

\footnotetext{
${ }^{87}$ See Paul Beck \& Ganapathi Narayanamoorthy, 'Did the SEC impact banks' loan loss reserve policies and their informativeness?', (2013), 56 Journal of Accounting and Economics, 42. See also Iftekhar Hasan \& Larry D. Wall, 'Determinants of the Loan Loss Allowance: Some Cross-Country Comparisons', (2004), 39 Financial Review, 129-130.

${ }^{88}$ See Moody's, Moody's Investors Service, 'Rated Bank Defaults and Government Support During the Crisis: A New Database and Study’, (2016), available at

https://www.moodys.com/research/Moodys-publishes-a-study-of-bank-defaults-and-governmentsupport--

PR_353029?WT.mc_id=AM RmluYW56ZW4ubmV0X1JTQ19SYXRpbmdzX05ld3NfTm9fVHJhbn NsYXRpb25z 20160801_PR_353029.

${ }^{89}$ Benoit Mesnard, Marcel Magnus \& Alienor Anne Claire Duvillet-Margerit, 'The precautionary recapitalisation of Monte dei Paschi di Siena', (2017), European Parliament Briefing, 3, available at http://www.europarl.europa.eu/RegData/etudes/BRIE/2017/587392/IPOL_BRI(2017)587392_EN.pdf. See also Christos Gortsos, 'Last resort lending to solvent credit institutions in the euro area before and after the establishment of the Single Supervisory Mechanism (SSM)', (2015), ECB Legal Conference paper, 12, available at https://ssrn.com/abstract=2688953.
} 